\title{
Ölüm Korkusu, Mahiyeti ve Nefsin Ölümden Sonraki Durumu ${ }^{1}$
}

\author{
İBN MISKEVEYH \\ ÇEV. İBRAHIM ASLAN \\ YRD.DOÇ.DR., ANKARA Ü. ILAHIYAT FAKÜLTESI \\ aslan@divinity.ankara.edu.tr
}

Rahman ve Rahim Olan Allah'ın Adıyla.

Hamd, kendisine hakkıyla şükredenlerin övgüsüyle âlemlerin Rabbi Allah'a; Salât, Hz. Muhammed'e ve onun pâk ailesinedir.

Ölüm, insanın başına gelen en büyük korkulardan birisidir. Bu korku, genel olmasina rağmen bütün diğer korkulardan daha şiddetli ve derindir. [Bu bakımdan] şunu söylemem gerekir: Ölüm korkusu, sadece, ölümün mahiyetini ve nefsinin geleceğini bilmeyen, vadesi geldiğinde ve [beden] yapısı bozulduğunda zâtının yok olup gideceğini ve nefsinin silinip gitmesi ve yok olması anlamında hükmünün ortadan kalkacağını zanneden kişinin başına gelebilecek bir şeydir. Çünkü kişi, nefsin bekâ ve meâd keyfiyetine ilişkin herhangi bir bilgisi olmayan biri olarak, kendisi hayatta olsun ya da olmasın, âlemin kendisinden sonra var olmaya devam edeceğini varsayar. Çünkü o, ölümün,

1 Çevirisini yaptı̆̆ımız risâle, İslam dünyasında Neoplatonik geleneğin ortaya çıkmasında önemli yeri

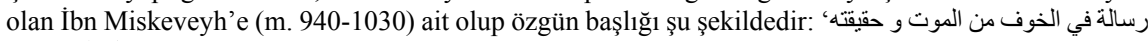

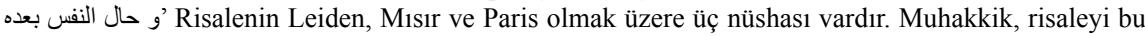
üç nüsha üzerinden tahkik etmiştir. İçerik açısından bakıldığında risale, insanın ölümlü oluşu gerçeğinden kaynaklanan 'varoluşsal' ve 'psikolojik' gerilimini, felsefe geleneğinin ruhun ölümsüzlüğü teziyle aşmaya çalışmakta ve ölüm gerçeğinin, insan ruhuna değil sadece bedene arız olan bir durum olduğunu ortaya koymaktadır. Bkz. İbn Miskeveyh, 'رسالة في الخوف من الموت و حقيقته و حال النفس بعده', Islamic Philosophy içinde, Volume: 86, edited by Fuat Sezgin, Frankfurt 2000, ss.103-114. 
ölümden önce gelen ve onun gerçekleşme nedeni olan hastalık elemlerinden ayrılan büyük bir elem olduğu zannını taşır, ya da ölümden sonra kendisini bekleyen müeyyidelerin olduğuna inanır, ölümden sonra kendisini neyin beklediğini bilmemenin şaşkınlığı veya ardında bırakacağ 1 mal ve kazanımların üzüntüsü içerisinde olur. [Esasında] bütün bunlar, gerçeklik değeri olmayan temelsiz varsayımlardan ibarettir.

Ölüm bilgisine sahip olmayan ve onun mahiyetini idrak etmemiş olan kişiye gelince, biz, ona, ölümün, nefsin, -bir şeyi imal eden kişinin kullanmak durumunda olduğu aletleri terk etmesi gibi- aletlerini yani tamamı 'beden' olarak isimlendirilen organlarını kullanmayı terk etmesinden başka bir şey olmadığını açıklayacağız. Çünkü nefs, cismanî olmayan bir cevherdir. [Bu niteliğiyle o], araz olmadığı gibi fesadı da kabul etmeyen bir şeydir. Bu açıklama, yeri geldiğinde detaylı olarak açıklanan öncül bilgilere gereksinim duymaktadır. Cevher bedeni terk ettiğinde, sahip olduğu bekâ niteliğini sürdürür, tabiatın kederinden sıyrılır ve tam bir saadete kavuşur. [Dolayısıyla] burada cevherin fani ve yok olması gibi bir durum hiçbir şekilde söz konusu değildir. Çünkü o, özselliği açısından son bulmaz ve yok olmaz, ancak, arazlar, nitelikler ve cevher ile cisimler arasinda var olan nispet ve vasiflar zitlarıla birlikte sona erer. Cevhere gelince onun zıddı yoktur, bozuluş hükmündeki her şey, ancak, zıddına göre bozulur. Kerîm olan bu [cismanî olmayan] cevherden daha aşağı düzeyde bulunan 'cismanî cevher'i düşünür ve hâli üzerinde inceleme yaparsan, onun fani olmayan ve cevheri bakımından yok olmayan, bazısının bazısına dönüşmesinin imkânsız olduğunu ve kendisinden bir şey olarak arazların ve niteliklerinin yok olduğunu keşfedersin. Cevherin kendisine gelince ise o, bakîdir, yok olması ve ortadan kalkması da söz konusu değildir. 'Ruhânî cevher' ise, zatında dönüşüm ve değişimi kabul etmez. $\mathrm{O}$, ancak olgunlaşmay1 [kemâlât] ve sûret almayı kabul eder. [Dolayısıyla] ruhanî cevhere ilişkin olarak yok olma ve sona ermeden nasıl söz edilebilir?

Nefsini nasıl bir geleceğin beklediğini bilmeyen veya bedeni dağıldığında ve yapısal bütünlüğü ortadan kalktığında sahip olduğu zâtı'nın da dağılacağını ve nefsinin sona ereceğini zanneden ve nefsin bekâ ve meâdından haberdar olmayan kişiye gelince, o, aslında, bizzat ölümden değil, bilinmesi gereken hususları bilmemesinden kaynaklanan bir korku içerisindedir. [Şu halde] cehalet, bir korku nedeni olması dolayısıyla korku kaynăgıdır. İşte filozofların 
bilme arzu ve çabası içerisinde olmalarının, uğrunda cismin lezzetlerini ve bedenin rahat olabileceği durumları terk ederek yorgunluk ve uykusuzluğu tercih etmelerinin temel nedeni bu cehalettir. Bu nedenle onlar, gerçek rahatlığın bilgisizlikten kurtulmakla sağlanabileceğini, gerçek zorluğun da nefsi müzminleştirecek bir hastalık olan cehalet olduğu görüşüne sahip olmuşlardır. Cehalet hastalığından kurtulmak ve iyileşmek, sonsuz bir huzur ve ebedî bir lezzettir. [Bu sebeple] filozofların gözünde dünyevî işler, kesinlik yargısına ulaştıklarında ve aydınlandıklarında, hakikat üzerinde yoğunlaştıklarında, huzur ve rahata erdiklerinde, kendilerine son derece önemsiz görünmüş; insanların yücelttikleri mal, servet, bedensel lezzet ve buna götüren bütün ihtiyaçlarını da kalıcılıkları ve süreklilikleri az, çabuk gelip geçen, var iken kaygısı çok, yok iken kederi büyük değersiz şeyler olarak görmüşler ve yaşamlarında dünyevî gereksinimlerin asgarisiyle yetinmişlerdir. Onlar, yukarıda ifade ettiğim ve etmediğim kusurlarından dolayı ihtiyaç fazlasına hiç iltifat etmemişlerdir. Çünkü ihtiyaç fazlasında sonu gelmeyen eksiklikler vardır. Zira insan, hedeflediği bir gayeye ulaştığında, bu durum onu, kendisinden korkulmayan ölüme dek hiç durmadan devam edecek olan başka bir gayeye çağıracaktır. [Bu anlamdaki] bir hırs, geçici olup böylesi bir şeyle meşgul olmak da boş bir meşguliyettir. Bu nedenle fillozoflar, iki tür ölümün bulunduğuna hükmetmişlerdir: ‘İradî Ölüm' ve 'Tabiî Ölüm'. Aynı şekilde iki tür hayat vardır: 'İradî Hayat' ve 'Tabiî Hayat'. Onlar, iradî ölümden arzuları öldürmeyi ve onlara eğilim göstermeyi terk etmeyi; iradî hayattan, insanın dünya hayatında yiyecek, içecek ve arzu olarak uğrunda çaba sarf ettiği şeyleri; tabiî hayatla da ebedî olan nefsin bilgisizlikten uzak durarak ve [sürekli] bilgilenerek ebedî mutluluk içinde bakî olmayı kastetmişlerdir. Bu sebeple filozof Eflatun, hikmeti şu sözle dile getirmiştir: "İrade açısından ölü, tabiatın açısından diri ol."

Diğer taraftan tabiî ölümden korkanlar, kuşkusuz, anlaşılabilir bir korku içindedirler. Böylesi bir ölüm, aslında, insanın [nihaî yaşam] sınırının tamamlanmasıdır. Çünkü insan, düşünen, ölümlü bir canlıdır. Ölüm de insanın kemâle ermesi, olgunlaşması ve en üst düzeye ulaşmasıdır. Kişi, her şeyin kendisi gibi bileşik bir mahiyete sahip olduğunu, mahiyetin cins ve fasıl'dan oluştuğunu; cinsinin, canlılık [niteliğine sahip olması], fasıllarının ise düşünen ve ölümlü oluşu anlamına geldiğini bilirse, ölüm ile kendisinin cins ve fasıllarına dönüştüğünü de bilmiş olur. Çünkü her bileşik varlık, kesinlikle, yapısında bulunan 
şeye dönüşür. [Dolayısıyla] zatının kemâle ermesinden endişe eden kişiden daha cahil, hayatının tükeneceğini ve sona ermesiyle de eksileceğini zanneden kişiden daha kötü kişi olabilir mi? Şu halde nâkıs kişi, kemâle ermekten korkarsa, cehaletin en üst seviyesinde olmuş olur. Bu sebeple akıl sahibi kişinin eksiklikten uzak durması, kemâle yakın olması, kendisini kemâle erdirecek, olgunlaştıracak, onurunu artıracak ve değerini yükseltecek, [zâtını] bağlayacak, güçlendirecek ve artıracak yönden değil, kendisini endişelere düşmekten koruyacak yönden bağını çözecek şeyi talep etmesi ve yüce ilahî cevhere güvenmesi gerekir. Kişi, sadece yoğunlaşmış haldeki cismanî cevherinin sahip olduğu karakterden ve içinde bulunduğu kederlerden kurtulduğunda değil, [bilakis cismanî bütün bağlarından] arındığında ve saflaştı̆̆ında mutluluğa ulaşır, aşkın âleme geri döner, Rabbine yakınlaşır, hoşnut ruhlar arasına karışarak ve bu ruhların zıtlarından kurtularak âlemlerin Rabbine yakın olmaya muvaffak olur. Tam da bu noktada, kişi, nefsi bedenini terk eden kişinin, asıl, nefsi bedenini arzu ettiğinde, ona karşı aşırı duyarlı olduğunda ve ondan ayrılmaktan endişe duyduğunda, kökleri zât ve cevherin [benliğin] en derinlerine kadar giden, dinmesi istenen fakat çaresi bulunmayan büyük bir mutsuzluk ve hüzün içerisinde olduğunu bilir.

Ölümün, zaman olarak önce gelen ve diğer hastalıkların neden olduğu elemlerden ayrılan büyük bir elem olduğunu zanneden kişiye gelince, o, bu konuda büyük bir zann içerisindedir. Çünkü elem, sadece "hayy" olan için söz konusu olabilir. Hayy, nefsin etkisine açı bir şeydir. Cisim ise, kendisinde nefsin etkisinin bulunmadığ 1 bir şeydir. O, hissetmeden acı çeker. Şu halde cisim, nefsin bedeni terk etmesi anlamına gelen ölüm ile acı çekmez. Çünkü beden, çektiği acıyı sadece nefis ile ve etkisinin meydana gelmesiyle hisseder. Nefsin hiçbir belirtisinin bulunmadığ cismin hissetme ve acı çekme niteliği yoktur. Dolayısıyla ölüm, beden tarafından hissedilemeyen ve eleme zemin olmayan bir halidir. Zira beden, sadece, nefis ile hisseder ve acı çeker.

Ölümden 'ceza' olduğu için korkan ise, esasında, bizzat ölümden değil, bilakis ölümden sonra karşı karşıya kalacağı cezadan korkmaktadır. Çünkü ceza, ancak, ölümden sonra kalıcı bir durum üzere olmayı ifade eder. Bu yönüyle o, kişinin cezayı gerektiren kötü fiillerini ve günahlarını itiraf etmesi anlamına gelmektedir. Bunun yanı sıra o, sadece kötülükleri cezalandıran adil bir otoriteyi benimsemeyi de içerir. Şu halde cezadan korkan kişi, esasında ölümden 
değil günahlarından korkmaktadır. Günah karşılığı olarak cezalandırılmaktan korkan kişinin günah işlemekten uzak durması gerekir. Günah olarak isimlendirilen değersiz fiiller, ancak, değersiz durumlardan doğar. Değersiz fiiller, kaydettiğimiz rezilliklerin kendisi ve faziletlerin zıtlarıdırlar. Dolayısıyla, bu gerekçelerle ölümden korkan kişi, korku gerekçesi olamayacak şeyden korkması dolayısıyla kendisinden korkması gereken konusunda tam bir bilgisizlik içerisindedir. Bu durumun tedavisi ise bilgidir. Çünkü bilen kişi, güven içerisinde olur, mutluluğun yolunu bilir ve bu yolda olur. Dininde kesin bilgi sahibi ve onun hikmetiyle kemâle eren kişinin hâli, kesinlikle, hedefe doğru yolu izleyerek ulaşmak isteyen kişinin bilgiyle yakinîlik ifade eden bir güven hâlidir.

Ölümden korkmadığını iddia edene gelince, o, esasında, geride bırakacağ 1 ailesine, çocuklarına, servetine içten içe yanar ve kaçıp gidecek olan dünyevî lezzetlere ve arzulara üzülür. Bu durumda kişinin, elem ve sevimsizlik dolayısıyla üzülmesinin kendisine hiçbir fayda sağlamayacağını, kendisinin yaratılmış olan diğer insanlar cümlesinden olduğunu, her yaratılmış olan şeyin kaçınılmaz olarak fesada uğrayacağını, fesada uğramamayı istemenin "var olmamayı" istemek, var olmamayı istemenin zâtının fesada uğramasını istemek anlamına geleceğini, bu durumda ölümden korkmanın, aynı anda, fesada uğramayı ve uğramamayı, olmayı ve olmamayı istemek gibi muhal [çelişik] bir durum olduğunu kendisine izah etmesi gerekir.

Kaldı ki insanın bakî olması mümkün olsaydı, bunun bizden öncekiler için mümkün olması, nesiller boyu devam etmesi, ölmemeleri ve yeryüzünün onlara dar gelmesi gerekirdi. Sanırım meramım şu sözlerle daha da açıklık kazanmış olacaktır. Dört yüz yıl öncesinden bu güne yaşamını sürdüren bir kişi olsaydı, -varsayalım ki bu kişi Hz. Ali [Allah kendisinden razı olsun] gibi insanlar arasında şöhret bulmuş biri olsun-, çocukları ve ondan sonraki iki kuşak da yaşamaya devam etmiş olsaydı, onlar, bu şekilde çoğalmaya devam ediyor ve ölmeden yaşamlarını sürdürüyor olsalardı, acaba, dört asır öncesinden bu güne onlardan kaç kişi olmuş olurdu? [Muhtemelen] on milyonun üzerinde kişi bulmuş olurdun. Bu sebeple, kendileri için ölüm takdir edilmekle birlikte, bu gün için onlardan geri kalan kişi sayısı yüz binin üzerinde olurdu. Aynı şeyi bu asırda yaşayanlar için düşündüğünde, sayının katlanarak artacağını ve sayılamayacak bir rakama ulaşacağını rahatlıkla anlayabilirsin. Daha sonra bu 
kişileri kapasitesi sınırlı olduğu bilinen dünyaya [yerleşim için] yaydığında, dağınık ve geniş alanlarda kendilerine yer bulmaları bir yana, dünyanın bu kişilere, ayakta ve istiflenerek bile yetmeyeceğini, ne uygun koşullarda mülk edinmeye ne de toprağı işlemeye ve dolaşıma elverişli olmayacağını [rahatlıkla] anlayabilirsin. Belirli bir zaman dilimi için hal böyleyken, acaba zaman uzadığında durum nasıl olurdu?

Ebedî hayatı temenni edip ölümden hoşlanmayan ve ebedî hayatın bilgisizlikle mümkün olduğunu zanneden kişinin durumu budur. Hâlbuki nihaî hikmet, ilahî nizam ve [intizam] ile kapsamlı hale gelen adalet, kendisinde sapma olmayan bir gerçekliktir. O, ötesinde başka gayenin olmadığı nihaî cömertliktir. Ölümden korkan, esasında Allah'ın adalet ve hikmetinden korkmuş olmaktadır. Hatta O'nun cömertlik ve ihsanından korkmaktadır. Şu halde ölüm, insanların zannettiği gibi kötü bir şey değildir. Asıl kötü olan ondan korkmaktır. Ondan korkan kişi, özü ve hakikati nefsin bedeni terk etmesinden ibaret olan ölüm konusunda bilgiden yoksundur. Nefsin bedeni terk etmesi, nefsin bozuluşu değil, bedensel yapının (terkîb) bozulmasıyla ilgili bir durumdur. Nefsin cevheri, insanın özü, aslı ve hülasasıdır. Bu niteliyle o, bakîdir. O, cisim olmanın gerektirdiği [niteliklere gereksinimi] olmadığı gibi, cisimlerin arazları için geçerli olan her hangi bir şeye, yani bir mekânda bulunmaya da gereksinimi yoktur. Çünkü o, mekâna ihtiyaç duymaz ve zamandan müstağni olduğu için zamansal bekâya da meyletmez. Bu cevher, sadece, kemâl açısından duyulardan ve cisimlerden istifade eder. Nefis, kemale erip duyulardan ve cisimlerden kurtulduğunda yüce âleme, Rabbine ve yaratıcısına döner. Kişinin ölü kardeşi için sadaka vermesi ve üzerinde kalan borcunu ödemesi, ölüyü sevindirir. Bu sebeple nefis, kadim filozofların iddia ettikleri gibi tek olsa da, sadaka verenin kendisi, yerine sadaka verilen kişi ve diğerleri tek kişi olmasalar da bir şeydir. Sadaka veren kişi, iyiliği, sadece, o nefse andırmak için yapmıştır. Bir şey nitelemesi bu yönüyle yapılmıştır. Esen kalın.

Risâle burada sona erdi. Hamd yalnız Allah'a, salât ve selâm kendisinden sonra nebînin bulunmadığı Hz. [Muhammed'e], ailesine ve ashabına olsun. 